\title{
MONTENEGRO SKIN TEST AND AGE OF SKIN LESION AS PREDICTORS OF TREATMENT FAILURE IN CUTANEOUS LEISHMANIASIS
}

\author{
Liliane de Fátima ANTONIO(1), Aline FAGUNDES(1), Raquel Vasconcellos Carvalhaes OLIVEIRA(2), Priscila Garcia PINTO(1), \\ Sandro Javier BEDOYA-PACHECO(1), Érica de Camargo Ferreira e VASCONCELLOS(1), Maria Cláudia VALETE-ROSALINO(1,3), \\ Marcelo Rosandiski LYRA(1), Sônia Regina Lambert PASSOS(2), Maria Inês Fernandes PIMENTEL(1) \& Armando de Oliveira SCHUBACH(1,4)
}

\begin{abstract}
SUMMARY
A case-control study was conducted to examine the association among the Montenegro skin test (MST), age of skin lesion and therapeutic response in patients with cutaneous leishmaniasis (CL) treated at Evandro Chagas National Institute of Infectious Diseases (INI), Oswaldo Cruz Foundation (FIOCRUZ), Rio de Janeiro, Brazil. For each treatment failure (case), two controls showing skin lesion healing following treatment, paired by sex and age, were randomly selected. All patients were treated with $5 \mathrm{mg} \mathrm{Sb}{ }^{5+} / \mathrm{kg} / \mathrm{day}$ of intramuscular meglumine antimoniate $\left(\mathrm{Sb}^{5+}\right)$ for 30 successive days. Patients with CL were approximately five times more likely to fail when lesions were less than two months old at the first appointment. Patients with treatment failure showed less intense MST reactions than patients progressing to clinical cure. For each $10 \mathrm{~mm}$ of increase in MST response, there was a $26 \%$ reduction in the chance of treatment failure. An early treatment - defined as a treatment applied for skin lesions, which starts when they are less than two months old at the first appointment -, as well as a poor cellular immune response, reflected by lower reactivity in MST, were associated with treatment failure in cutaneous leishmaniasis.
\end{abstract}

KEYWORDS: Skin tests; Cutaneous leishmaniasis; Treatment failure.

\section{INTRODUCTION}

American tegumentary leishmaniasis (ATL) is an anthropozoonosis widely spread throughout Brazil. There were 21,866 new cases in $2010^{5,8}$, with two main forms: cutaneous leishmaniasis (CL) and mucosal leishmaniasis. The localized form of CL, presenting as single or multiple ulcers, is the most typical one 5 .

Culture of biopsy specimens of suspected lesions and the direct smear of material obtained from the lesion are the main confirmatory tests. Diagnosis may also be established by detection of parasites in histological specimens and by the polymerase chain reaction ${ }^{13}$. Due to high cost and technical complexity of tests, culture parasite and molecular detection of Leishmania in Brazil are restricted to the reference centers for this disease $\mathrm{e}^{5,13}$. The Montenegro skin test (MST), with a sensitivity rate of $86.4 \%$ up to $100 \% \%^{6,15,23,29}$, is the main diagnostic test in primary care. In the presence of a suspicious cutaneous lesion, MST supports the diagnosis of Leishmania infection. Skin reactions to MST $\geq 5 \mathrm{~mm}$ are considered positive and $<5 \mathrm{~mm}$ are considered negative ${ }^{5}$. Patients with negative MST and diagnostic confirmation by other tests are more prone to relapse ${ }^{22}$. MST is a marker of cellular immune response ${ }^{10}$, evaluating type IV hypersensitivity response mediated by $\mathrm{T}$ cells ${ }^{28}$. However, it may be influenced by clinical presentation ${ }^{18}$ and by disease duration ${ }^{7,15}$.
The first choice for CL drug treatment in Brazil is meglumine antimoniate $\left(\mathrm{Sb}^{5+}\right)^{5}$. The Brazilian Ministry of Health (2010) recommends $10-20 \mathrm{mg} \mathrm{Sb}^{5+} / \mathrm{kg} /$ day for 20 days. However, clinical studies in Rio de Janeiro suggest that $5 \mathrm{mg} \mathrm{Sb}{ }^{5+} / \mathrm{kg} /$ day for 30 days may be easier to deliver, allowing effective treatment of the disease, with lower toxicity and cost ${ }^{19-21}$.

Therapeutic failure is defined by DEPS et al. (2000) as lack of clinical response during and after the treatment, with stabilization or worsening of the ulcerated lesion ${ }^{12}$. In individuals treated with meglumine antimoniate with $10-20 \mathrm{mg} \mathrm{Sb}^{5+} / \mathrm{kg} /$ day, therapeutic failure varies from $46 \%$ to $75 \%$ 12,25,31,32 . Factors related to therapeutic failure include: three or more cutaneous lesions, prior treatment to leishmaniasis, weight exceeding $68 \mathrm{~kg}$ and irregular treatment ${ }^{27}$.

In this study, the association among MST, age of cutaneous lesion and therapeutic response in patients with CL was evaluated.

\section{MATERIALS AND METHODS}

1. Study design: This was an observational retrospective casecontrol study, with localized CL patients who attended the Leishmaniasis 


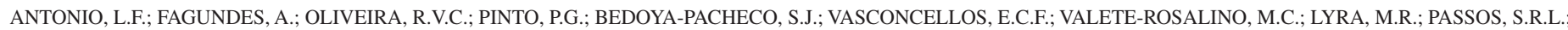
PIMENTEL, M.I.F. \& SCHUBACH, A.O. - Montenegro skin test and age of skin lesion as predictors of treatment failure in cutaneous leishmaniasis. Rev. Inst. Med. Trop. Sao Paulo, 56(5): 375-80, 2014.

Surveillance Laboratory (Lab Vigileish) at Evandro Chagas National Institute of Infectious Diseases (INI), Oswaldo Cruz Foundation (FIOCRUZ), Rio de Janeiro, Brazil, between January 1989 and December 2009.

2. Inclusion criteria: Patients with CL diagnosis made by parasitological criteria (culture of Leishmania in appropriate media, parasites seen at histological exam or direct smear and/or imprint of a biopsy specimen; or Leishmania DNA detection by polymerase chain reaction) and/or epidemiological (patients living or travelling to endemic areas) and/or clinical (suggestive cutaneous lesions) and/or immunological criteria (Leishmania serology - indirect immunofluorescence reaction and/or immunoenzymatic assay) were included. They were treated with intramuscular meglumine antimoniate $5 \mathrm{mg} \mathrm{Sb}^{5+} / \mathrm{kg} /$ day for 30 consecutive days ${ }^{29}$.

3. Exclusion criteria: Patients with other clinical forms of CL, without register of MST in millimeters, lack of post-treatment followup for at least two years, and/or those presenting relapse after an initial response (temporary healing) were excluded.

4. Selection of cases and controls: Therapeutic failures, defined as the non-occurrence of progression to definitive scar formation after the initial treatment, were considered as cases.

Patients with permanent clinical cure, defined as the epithelization of the ulcerated lesions with progressive disappearance of crusts, scaling, infiltration and erythema, with a final establishment of an atrophic, hypertrophic or imperceptible scar, as well as the lack of mucosal lesion after the initial treatment, were considered as controls. Controls were randomly selected among the patients with clinical cure and were matched by sex and age range to the cases in the proportion of 2:1. Matching was performed according to the following age ranges: 5-9; 10-14; 15-19; 20-24; 25-29; 30-34; 35-39; 40-45; 46-50; 51-55 years.

5. Data analyses: Description of the data was made using simple frequencies of categorical variables (most probable area of infection; circumstances of exposure; results of MST, parasitological, serological and histopathological exams; co-morbidities; number of lesions; site of lesions; and age of lesions), and with average and minimum/maximum of continuous variables (number of lesions; MST in millimeters; duration of disease before treatment; and time until the occurrence of therapeutic failure).

The McNemar test was used for comparison of categorical variables between cases and controls, and the Wilcoxon test was used for continuous variables, when normality hypothesis was rejected by the Kolmogorov-Smirnov test.

Simple models of binary conditional logistic regression were used to evaluate the effect of each variable in the occurrence of therapeutic failure (age of cutaneous lesion, number of lesions, site of lesions, co-morbidities, MST in millimeters, and positivity of serology, histopathology and culture). After that, a multiple model was performed to therapeutic failure, adjusted by the same characteristics. The likelihood ratio test was used to indicate the best adjusted model. Odds ratio (OR) and its respective confidence interval (CI) was used as a measure of the association among the variables in the regression models.
MST in millimeters was used and, due to the lack of normal distribution, it was performed using its logarithm. Consequently, the application of anti-logarithm was used to the analysis of the results.

$p$-values $<0.05$ indicated significant association in the performed tests.

Data were analyzed with the Statistical Package for the Social Sciences (SPSS-WIN) version 16.0 and STATA 10.0 softwares.

\section{RESULTS}

From 800 ATL patients followed-up in the studied period, 634 $(79.25 \%)$ presented CL. Four hundred and seven individuals were excluded from the study (Fig. 1).

From 227 eligible patients, 32 (14.1\%) evidenced therapeutic failure, and 64 matched controls were selected, with 96 patients being included in the study. Studied population included $59.4 \%$ men, with age varying between five and 55 years. For $89.6 \%$, the probable place of infection was Rio de Janeiro State and $64.6 \%$ were from rural areas. Ninety seven per cent of the studied patients lived and/or had previously been in endemic areas for the disease. All patients with negative MST resided in endemic areas. Three of the subjects had no data concerning the place of residence or travels to endemic areas, and all of them showed strong MST reaction.

Main exposure motive in $93.8 \%$ of the patients was domicile. Comorbidities were observed in $34.4 \%$ of the patients, the most frequent being anemia, arterial hypertension, thyroid disease, atopic disease, smoking and tuberculosis. Data regarding HIV-serology, use of drugs or other diseases that could compromise immunity were not found in the studied records.

Culture, serology and histopathology for leishmaniasis were positive in $78.1 \%, 62.5 \%$ and $63.5 \%$, respectively. Among the case group, all patients had parasitological confirmed diagnosis. In the control group, 60 patients had parasitological confirmation, two had epidemiological, clinical and serological diagnosis, and two had epidemiological and clinical diagnosis. As a prerequisite for inclusion in the control group, all patients had had a good response to antimonial treatment. All of the four control subjects who had no parasitological confirmed diagnosis underwent mycological examination with negative results; all of them had a positive MST; and two had chronic granulomatous infiltrate in histopathology of the cutaneous lesion, suggestive of leishmaniasis. No significant difference among these variables and the occurrence of therapeutic failure was found.

Average time to detection of therapeutic failure after the end of the treatment was 93 days, varying from 18 to 316 days. In the control group, the average in days until definitive scar formation was 194 days and varied from 51 to 418 days.

There was a significant difference in cases regarding the age of the skin lesion prior to the diagnosis. Cases with lesions that were less than two months old at the first appointment were $71.9 \%$, compared to $35.9 \%$ for controls $(p<0.001)$.

MST reactivity in millimeters also exhibited significant difference 


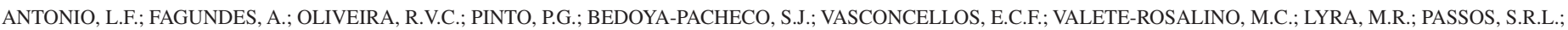

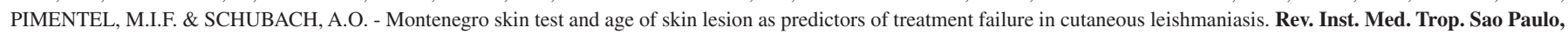
56(5): $375-80,2014$

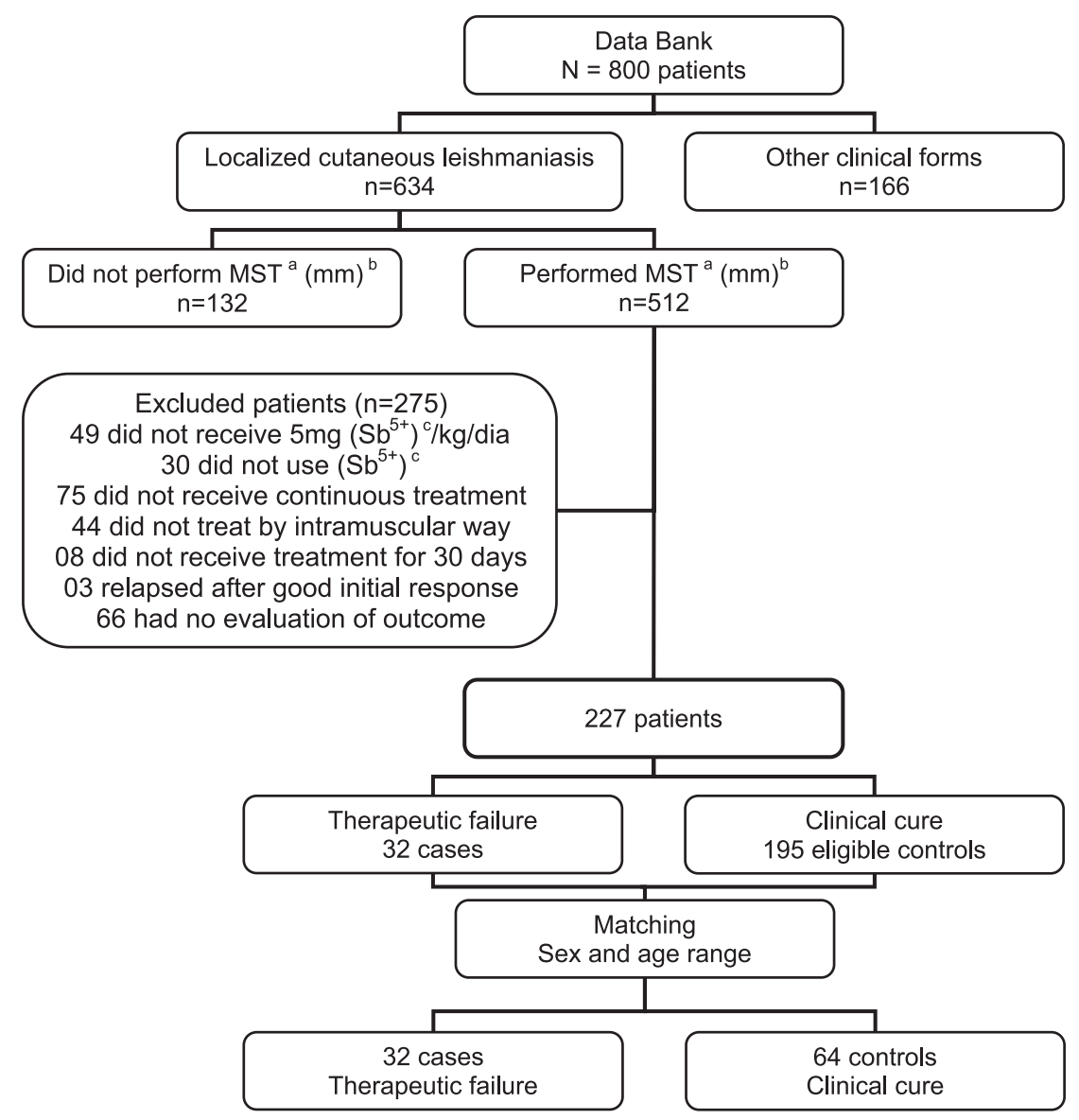

${ }^{\mathrm{a}} \mathrm{MST}=$ Montenegro skin test; ${ }^{\mathrm{b}} \mathrm{mm}=$ millimeters; ${ }^{\mathrm{c}} \mathrm{Sb}^{5+}=$ meglumine antimoniate.

Fig. 1 - Selection of cases and controls after analysis of the Data Bank of Lab Vigileish, INI/FIOCRUZ, 1989 to 2009 , Rio de Janeiro, Brazil.

between cases and controls $(p=0.027)$. In cases, MST varied from 0 to $60 \mathrm{~mm}$, with median of $13.5 \mathrm{~mm}$; and in controls, it varied from 0 to 50 $\mathrm{mm}$, with median of $17.5 \mathrm{~mm}$. However, significant difference between groups was not observed when comparing MST using $5 \mathrm{~mm}$ as a cut-off (positive or negative) $(p=0.289)$.

Age of skin lesion and the LogMST were significant regarding the occurrence of therapeutic failure in the simple model of conditional logistic regression, $p<0.001$ and $p=0.026$, respectively. Other variables (number of lesions, site of the lesion, co-morbidities, serology, histopathology and culture) were not statistically significant in the simple regression model (Table 1).

The likelihood ratio test indicated a final multiple logistic model constituted by the LogMST in millimeters (adjusted OR: 0.26 / CI: $[0.09-0.77] / p=0.015)$ and by the age of the skin lesion (adjusted OR: 6.33 / CI: $[2.52-15.90] / p<0.001)$, and there was no significant interaction between these two variables. Patients with skin lesions less than two months old had 5.33 more chances of therapeutic failure than those with skin lesions more than two months old. For each 10 millimeters of increase in MST, there was a decrease of $26 \%$ in the chances of occurrence of failure.
Table 1

Odds ratio (non-adjusted) of the conditional simple logistic regression model

\begin{tabular}{lccc}
\hline Variables & OR $^{\mathrm{a}}$ & $95 \%$ CI & $p$-value \\
\hline Evolution time before treatment & $\mathbf{5 . 6 4}$ & {$[\mathbf{2 . 3 5}-\mathbf{1 3 . 5 3}]$} & $<\mathbf{0 . 0 0 1}$ \\
LogMST $^{\mathrm{b}}$ & $\mathbf{0 . 3 2}$ & {$[\mathbf{0 . 1 2}-\mathbf{0 . 8 7}]$} & $\mathbf{0 . 0 2 6}$ \\
Number of lesions & 1.19 & {$[0.53-2.68]$} & 0.679 \\
Site of the lesion & 1.15 & {$[0.56-2.37]$} & 0.712 \\
Co-morbidities & 0.60 & {$[0.25-1.47]$} & 0.268 \\
Serology positivity & 1.76 & {$[0.55-5.64]$} & 0.345 \\
Histopathology positivity & 1.75 & {$[0.70-4.34]$} & 0.229 \\
Culture positivity & 1.23 & {$[0.26-5.69]$} & 0.793
\end{tabular}

adds ratio; ${ }^{b}$ Log skin test Montenegro results in millimiters. 


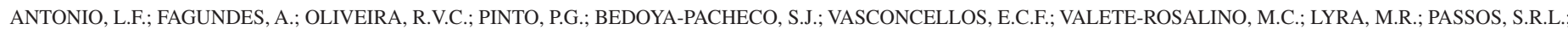
PIMENTEL, M.I.F. \& SCHUBACH, A.O. - Montenegro skin test and age of skin lesion as predictors of treatment failure in cutaneous leishmaniasis. Rev. Inst. Med. Trop. Sao Paulo, 56(5): 375-80, 2014.

\section{DISCUSSION}

This study evaluated the association between therapeutic response and clinical and laboratory parameters, defined as age of skin lesion and MST.

An inverse association between the intensity of MST reaction and the occurrence of therapeutic failure was observed, with strong reactors to MST being less susceptible to the occurrence of treatment failure.

There was a significantly higher chance of development of therapeutic failure in patients with lesions less than two months old at the first appointment.

The percentage of therapeutic failure $(14 \%)$ was lower than reported in previous studies with meglumine antimoniate treatment $(46 \% \text { to } 75 \%)^{12,27,29,33}$. Low failure rates found in this study support the effectiveness of low-dose treatment ( $5 \mathrm{mg} \mathrm{Sb} \mathrm{Sb}^{5+} / \mathrm{kg} /$ day) previously reported in studies at INI/FIOCRUZ ${ }^{19,29}$.

The fact that the majority of the studied population acquired the infection at their domicile is consistent with the peri-urban epidemiological profile of the disease in Rio de Janeiro ${ }^{6}$. Most of the subjects were from the state of Rio de Janeiro, where Leishmania (Viannia) braziliensis is responsible for almost all cases ${ }^{11}$.

MST has been used since the 1920s, when it was developed by MONTENEGRO $^{17}$. The importance of the standardization of the technique (application and reading) of MST and of the used antigen for its performance has been highlighted by several authors. The test must be performed by a trained technician, in order to assure comparable results and to avoid common causes of variation in the execution and interpretation of cutaneous tests, as follows: the amount of injected antigen; the site and deepness of the injection; the physiological status of the patient; the used vehicle; and the observer performing the measure ${ }^{3,16,35}$. Patients seen at Lab Vigileish, who performed MST in the institution, are always submitted to a standard protocol, ensuring the quality of the assistance in the test.

The safety and quality of the used antigen was ensured with the use of the antigen delivered by the Brazilian Ministry of Health, produced on a large scale within the standards of good practices ${ }^{1}$. Although the used strain is Leishmania (Leishmania) amazonensis, it is produced to be used throughout the country, regardless of the species of Leishmania causing disease.

The main difficulty found in the study was the incomplete patients' records. The use of electronic records, however, turned easier the process of data collection.

Study population of referral centers have characteristics which may differ from the general population, and this is a possible selection bias in this study. An assessment of all patients with poor response to treatment followed-up during the study, in addition to the matching between groups, was the strategy chosen to decrease biases. However, internal validity of the study was guaranteed by homogeneity in the distribution of the groups.
Previous studies demonstrated higher rates of therapeutic failure in patients treated before the development of the cutaneous lesion; in those ones, treatment did not prevent the occurrence of the lesion ${ }^{14,34}$.

Reactivity to MST reflects the development of specific Th1 cellular immune response to the Leishmania parasite ${ }^{28}$. The development of adaptive immune response against leishmaniasis is the basis for the resistance to infection ${ }^{4}$. Usually, MST is used as an indicator of protection in vaccine evaluation studies against Leishmania ${ }^{9,10}$.

MST indicates the establishment of a cellular immune response against Leishmania antigens ${ }^{2,4,23}$. Low percentage of negative response to MST in this study confirms the high sensitivity of the test ${ }^{7,17,25,30}$. The proportion of patients with negative MST in the case group was twice that of the control group. The lack of statistical significance in MST analysis when classified in positive or negative may be related to the low proportion of negative tests ${ }^{27}$. PASSOS et al. suggested that a negative response to MST may function as a predictor of post-treatment relapse $\mathrm{e}^{22}$.

A defect of the host cellular immune response associated with the persistence of the parasite is a hypothesis to the occurrence of therapeutic failure or relapse $\mathrm{e}^{5,26,32}$. A negative response to MST after two months of disease evolution may be related to a defect of the host immune response. However, patients presenting definitive cure with negative MST indicate that other factors may also be related to the occurrence of cure or therapeutic failure.

Additional studies with the standard dose of meglumine antimoniate for CL (10 - $20 \mathrm{mg} \mathrm{Sb}^{5+} / \mathrm{kg} /$ day during 20 continuous days) and with different populations in other locations should be performed to confirm these results.

\section{CONCLUSION}

Early treatment, reflected by an evolution time of the lesion of less than two months at the first appointment, and a poor cellular immune response, reflected by a less intense MST, both demonstrated to contribute to the occurrence of treatment failure in cutaneous leishmaniasis in CL patients with intramuscular meglumine antimoniate in the dose of $5 \mathrm{mg}$ $\mathrm{Sb}^{5+} / \mathrm{kg} /$ day for 30 consecutive days. Clinicians should be aware of the possibility of therapeutic failure in the follow-up of negative MST patients and those who undergo treatment before the skin lesion is two months old.

\section{FUNDING}

This work received support from INI/FIOCRUZ and the National Council of Scientific and Technicological Development - Brazil (CNPq), which did not participate in the design, execution, or report.

\section{CONFLICTS OF INTEREST}

None declared.

\section{ETHICS CONSIDERATIONS}

This study follows National Health Council guidelines and was approved by the Ethics Committee on Human Research (CEP) of INI/ FIOCRUZ, number CAAE 0016.0.009.000-02. 


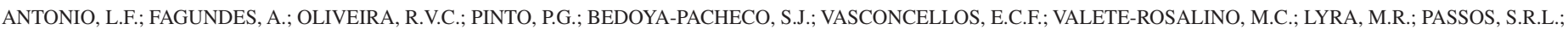

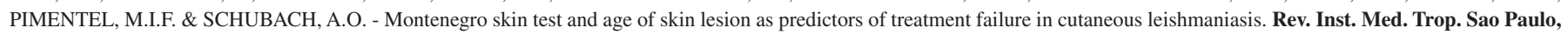
56(5): 375-80, 2014.

\section{RESUMO}

\section{Intensidade da intradermorreação de Montenegro e tempo de evolução da lesão como preditores de falha na resposta terapêutica da leishmaniose cutânea}

Conduzimos estudo caso-controle que verificou a associação entre a intradermorreação de Montenegro (IDRM), o tempo de evolução da lesão e a resposta terapêutica em pacientes com leishmaniose cutânea (LC) atendidos no Instituto de Infectologia Evandro Chagas (INI), Fundação Oswaldo Cruz (Fiocruz), Rio de Janeiro, Brasil. Para cada caso com má resposta à terapêutica foram selecionados aleatoriamente dois controles que evoluíram com cicatrização das lesões após o tratamento, pareados por sexo e idade. Todos os pacientes realizaram tratamento com antimoniato de meglumina $\left(\mathrm{Sb}^{5+}\right) \mathrm{IM}$, na dose de $5 \mathrm{mg}$ $\mathrm{Sb}^{5+} / \mathrm{kg} / \mathrm{dia}$, continuamente, por 30 dias. Pacientes com LC apresentaram aproximadamente cinco vezes mais chance de falhar quando as lesões apresentavam menos de dois meses de evolução no primeiro dia de atendimento. Pacientes com falha terapêutica apresentaram reações de IDRM menos intensas que pacientes que evoluíram para a cura clínica. A cada 10 milímetros de aumento na resposta à IDRM, houve uma redução de $26 \%$ na chance de ocorrência de falha. O tratamento precoce, traduzido pelo tempo de evolução da lesão menor que dois meses no primeiro dia de atendimento, e resposta de imunidade celular deficiente, traduzida por IDRM menos intensa, demonstraram contribuir para a ocorrência de falha terapêutica na leishmaniose cutânea.

\section{ACKNOWLEDGMENTS}

To the staff of LabVigiLeish - IPEC/FIOCRUZ-RJ for help and contribution.

\section{REFERENCES}

1. Antígeno de Montenegro. Bula do antígeno. Paraná: Centro de Produção e Pesquisa de Imunobiológicos - CPPI; 2008. [cited 2011 Oct 17]; Available from: http://www. saude.pr.gov.br/arquivos/File/CPPI/bulas/montenegro.pdf

2. Bacellar O, Lessa H, Schriefer A, Machado P, Ribeiro de Jesus A, Dutra W, et al. Upregulation of Th1-type responses in mucosal leishmaniasis patients. Infect Immun. 2002;70:6734-40.

3. Bearman JE, Kleinman H, Glyer VV, Lacroix OM. A study of variability in tuberculin test reading. Am Rev Respir Dis. 1964;90:913-9.

4. Ben Salah A, Louzir H, Chlif S, Mokni M, Zaatour A, Raouene M, et al. The predictive validity of naturally acquired delayed-type hypersensitivity to leishmanin in resistance to Leishmania major-associated cutaneous leishmaniasis. J Infect Dis. 2005;192:19817.

5. Brasil. Ministério da Saúde. Manual de vigilância da leishmaniose tegumentar cutânea $3^{a}$ ed. Brasília: Ministério da Saúde; 2010.

6. Bustamante MCFS, Pereira MJS, Schubach AO, Fonseca AH. Epidemiological profile of cutaneous leishmaniasis in an endemic region in the State of Rio de Janeiro, Brazil. Rev Bras Parasitol Vet. 2009;18:34-40.

7. Curti MCM, Silveira TGV, Arraes SMAA, Bertolini DA, Zanzarini PD, Venazzi EAS, et al. Epidemiological and clinical characteristics of cutaneous leishmaniasis and their relationship with the laboratory data, south of Brazil. Braz J Infect Dis. 2011;15:12-6.
8. DATASUS. Leishmaniose tegumentar americana: casos confirmados notificados no sistema de informação de agravos de notificação. Brasília: Ministério da Saúde/ SINAN; 2011. [cited 2011 Oct 17]. Available from: http://dtr2004.saude.gov.br/ sinanweb/tabnet/dh?sinan/lta/bases/ltabr.def

9. De Luca PM, Mayrink W, Alves CR, Coutinho SG, Oliveira MP, Bertho AL, et al. Evaluation of the stability and immunogenicity of autoclaved and nonautoclaved preparations of a vaccine against American tegumentary leishmaniasis. Vaccine. $1999 ; 17: 1179-85$

10. De Luca PM, Mayrink W, Pinto JA, Coutinho SG, Santiago MA, Toledo VP, et al. A randomized double-blind placebo-controlled trial to evaluate the immunogenicity of a candidate vaccine against American tegumentary leishmaniasis. Acta Trop. 2001;80:251-60.

11. De Oliveira-Neto MP, Mattos MS, Perez MA, Da-Cruz AM, Fernandes O, Moreira J, et al. American tegumentary leishmaniasis (ATL) in Rio de Janeiro State, Brazil: main clinical and epidemiologic characteristics. Int J Dermatol. 2000;39:506-14.

12. Deps PD, Viana MC, Falqueto A, Dietze R. Avaliacão comparativa da eficácia e toxicidade do antimoniato de N-metil-glucamina e do estibogluconato de sódio BP88® tratamento da leishmaniose cutânea localizada. Rev Soc Bras Med Trop. 2000;33:53543.

13. Gontijo B, Carvalho MLR. Leishmaniose tegumentar americana. Rev Soc Bras Med Trop. 2003;36:71-80.

14. Machado P, Araújo C, Da Silva AT, Almeida RP, D’Oliveira Jr A, Bittencourt A, et al. Failure of early treatment of cutaneous leishmaniasis in preventing the development of an ulcer. Clin Infect Dis. 2002;34:E69-73.

15. Manzur A, Bari Au. Sensitivity of leishmanin skin test in patients of acute cutaneous leishmaniasis. Dermatol Online J. 2006;12:2

16. Melo MN, Mayrink W, da Costa CA, Magalhaes PA, Dias M, Williams P, et al. Padronização do antígeno de Montenegro. Rev Inst Med Trop Sao Paulo. 1977;19:161

17. Montenegro J. A cútis-reação na leishmaniose. Ann Fac Med Univ Sao Paulo. 1926;1:32330 .

18. Nogueira MF, Goto H, Sotto MN, Cucé LC. Cytokine profile in Montenegro skin test of patients with localized cutaneous and mucocutaneous leishmaniasis. Rev Inst Med Trop Sao Paulo. 2008;50:333-7.

19. Oliveira LF, Schubach AO, Martins MM, Passos SL, Oliveira RV, Marzochi MC, et al. Systematic review of the adverse effects of cutaneous leishmaniasis treatment in the New World. Acta Trop. 2011;118:87-96.

20. Oliveira-Neto MP, Schubach AO, Mattos M, Gonçalves-Costa SC, Pirmez C. A low-dose antimony treatment in 159 patients with American cutaneous leishmaniasis: extensive follow-up studies (up to 10 years). Am J Trop Med Hyg. 1997a;57:651-5.

21. Oliveira-Neto MP, Schubach AO, Mattos M, Gonçalves-Costa SC, Pirmez C. Treatment of American cutaneous leishmaniasis: a comparison between low dosage ( $5 \mathrm{mg} /$ $\mathrm{kg} /$ day) and high dosage $(20 \mathrm{mg} / \mathrm{kg} /$ day) antimony regimens. Pathol Biol (Paris). 1997b;45:496-9.

22. Passos VM, Barreto SM, Romanha AJ, Krettli AU, Volpini AC, Lima e Costa MF. American cutaneous leishmaniasis: use of a skin test as a predictor of relapse after treatment. Bull World Health Organ. 2000;78:968-74.

23. Pessoa SB, Pestana BR. A intradermo-reação de Montenegro nas campanhas sanitárias contra a leishmaniose. Arq Hyg Saúde Publ. 1940;5:125-37.

24. Pirmez C, Yamamura M, Uyemura K, Paes-Oliveira M, Conceição-Silva F, Modlin RL. Cytokine patterns in the pathogenesis of human leishmaniasis. J Clin Invest. 1993;91:1390-5. 


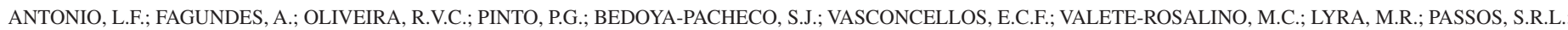
PIMENTEL, M.I.F. \& SCHUBACH, A.O. - Montenegro skin test and age of skin lesion as predictors of treatment failure in cutaneous leishmaniasis. Rev. Inst. Med. Trop. Sao Paulo, 56(5): 375-80, 2014.

25. Reis LC, Brito MEF, Almeida EL, Félix SM, Medeiros ACR, Silva CJ, et al. Clinical, epidemiological and laboratory aspects of patients with American cutaneous leishmaniasis in the State of Pernambuco. Rev Soc Bras Med Trop. 2008;41:439-43.

26. Reis LC, Brito MEF, Souza MA, Medeiros ACR, Silva CJ, Luna CF, et al. Cellular immune response profile in patients with American tegumentary leishmaniasis prior and post chemotherapy treatment. J Clin Lab Anal. 2009;23:63-9.

27. Rodrigues AM, Hueb M, Santos TARR, Fontes CJF. Fatores associados ao insucesso do tratamento da leishmaniose cutânea com antimoniato de meglumina. Rev Soc Bras Med Trop. 2006;39:139-45.

28. Sassi A, Louzir H, Ben Salah A, Mokni M, Ben Osman A, Dellagi K. Leishmanin skin test lymphoproliferative responses and cytokine production after symptomatic or asymptomatic Leishmania major infection in Tunisia. Clin Exp Immunol. $1999 ; 116: 127-32$

29. Schubach AO, Marzochi KBF, Moreira JS, Schubach TMP, Araújo ML, Vale ACF, et al. Retrospective study of 151 patients with cutaneous leishmaniasis treated with meglumine antimoniate. Rev Soc Bras Med Trop. 2005;38:213-7.

30. Silva AF. Avaliação do teste intradérmico de Montenegro em populações militares do Brasil: positividade e resposta inespecífica. [dissertação]. Rio de Janeiro: Fundação Oswaldo Cruz, Instituto Oswaldo Cruz; 1999.
31. Silva AF. A reação intradérmica de Montenegro na clínica e na epidemiologia da leishmaniose tegumentar. [tese]. Rio de Janeiro: Fundação Oswaldo Cruz, Instituto Nacional de Controle de Qualidade em Saúde; 2007.

32. Stefanidou MP, Antoniou M, Koutsopoulos AV, Neofytou YT, Krasagakis K, KrügerKrasagakis $\mathrm{S}$, et al. A rare case of leishmaniasis recidiva cutis evolving for 31 years caused by Leishmania tropica. Int J Dermatol. 2008;47:588-9.

33. Teixeira AC, Paes MG, Guerra JO, Prata A, Silva-Vergara ML. Failure of both azithromycin and antimony to treat cutaneous leishmaniasis in Manaus, AM, Brazil. Rev Inst Med Trop Sao Paulo. 2008;50:157-60.

34. Unger A, O'Neal S, Machado PRL, Guimarães LH, Morgan DJ, Schriefer A, et al Association of treatment of American cutaneous leishmaniasis prior to ulcer development with high rate of failure in northeastern Brazil. Am J Trop Med Hyg. 2009;80:574-9.

35. Weigle KA, Valderrama L, Arias AL, Santrich C, Saravia NG. Leishmanin skin tes standardization and evaluation of safety, dose, storage, longevity of reaction and sensitization. Am J Trop Med Hyg. 1991;44:260-71

Received: 3 September 2013

Accepted: 21 February 2014 